\title{
CONSTRUCTION SCHEDULING AND STABILITY OF THE RESULTING SCHEDULES
}

\section{KRZEMIŃSKI ${ }^{1}$}

\begin{abstract}
The paper present the concept of stability assessing the of solutions which are construction schedules. Rank have been obtained through the use of task scheduling rules and the application of the KASS software. The aim of the work is the choice of the equivalent solution in terms of the total time of the project. The selected solution optimization task should be characterized by the highest resistance to harmful environmental risk factors. To asses the stability of schedule simulation technique was used.
\end{abstract}

Keywords: construction scheduling, schedules stability, flow shop models, KASS

\section{INTRODUCTION}

A schedule is the basic tool used in construction project management. In the case of projects that involve rhythmical or sub-rhythmical processes, there are many rules like MS, FCFS, LPT, SPT, etc. can be used. Also we can use heuristics like shifting bottleneck or local search and many others that are developed every day [9],[10].

Construction processes are especially prone to risk. Uncertainty has become one of the major factors affecting project execution and ultimate success. The risk in construction business is very high. It's very important to work with the risk, one way is to choose most stable schedules[10].

Project planning for uncertainty and risk has been the subject of numerous research efforts since introduction of the PERT model. The existing methods that express activity durations as random values and simulation models focus mainly on estimating either the probability of conforming to the contractual completion date, or the project duration at a predefined confidence level.[4].

\footnotetext{
${ }^{1}$ PhD., Eng., Warsaw University of Technology, Faculty of Civil Engineering, Al. Armii Ludowej 16, 00-637 Warsaw, Poland, e-mail: m.krzeminski@il.pw.edu.pl
} 
A construction project is characterized by a high number of project participants[11], [12], [13]. The article will present the method of schedules stability assessment. I presented case schedules are project for flowshop production models. Suppose that we need to execute 5 consecutive actions on 12 workspaces. These are not processes of one type neither are they homogeneous [2]. To solve the task we would use a complete check. Calculations consisting of analysing 12 ! solutions will take only a moment. However, it may turn out that there is more than one line-up that meets the established criteria for the evaluation. It is therefore necessary to choose the best among the alternatives [8]. One of the evaluation methods could be the adoption of the assumption that the best part is the one closest to the one given as input. This assumption would be good only in the case where the introduction would be technologically optimal [3].

\section{STABILITY OF THE RESULTING SCHEDULES FOR CONSTRUCTION HOMOGENEOUS PROCESS WITH USE SPT AND LPT RULES}

A different approach which is worth taking into consideration according to the author is a choice of the safest one on account of the impact of risk factors. In this part of the paper an attempt was made to evaluate schedules on account of the assessment of schedule stabilization under impact of random factors. The first considered issue was the assessment of stability of two line-ups scheduled using SPT and LPT rules. The following table 1 shows the data on individual processes execution times in workspaces [9], [10].

Table 1. Input data

\begin{tabular}{|c|c|c|c|c|}
\hline & Workspace 1 & Workspace 2 & Workspace 3 & Workspace 4 \\
\hline Working Brigade A & 8 & 16 & 24 & 32 \\
\hline Working Brigade B & 8 & 16 & 24 & 32 \\
\hline Working Brigade C & 8 & 16 & 24 & 32 \\
\hline
\end{tabular}

The results of the scheduling with SPT method are shown in table 2.

Table 2. The results of the scheduling with SPT method

\begin{tabular}{|c|c|c|c|c|}
\hline & Workspace 1 & Workspace 2 & Workspace 3 & Workspace 4 \\
\hline EFT A & 8 & 24 & 48 & 80 \\
\hline EFT B & 16 & 40 & 72 & 112 \\
\hline EFT C & 24 & 56 & 96 & 144 \\
\hline
\end{tabular}


In addition, there are calculated completion times of each activity. Total work execution time is 144 . Due to the inability to determine the free time slack in this type of network model [1] it was decided to assign probability distributions to activities performed by the working brigade C. In figures 1-4 presented are triangular distributions that have been assigned to operations.

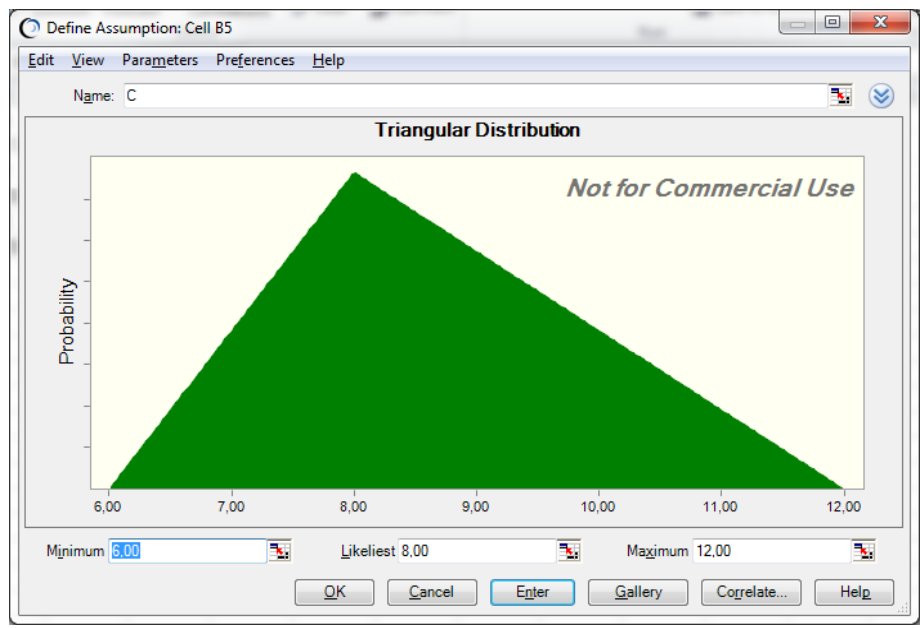

Fig. 1. Triangular distribution for the initial duration 8

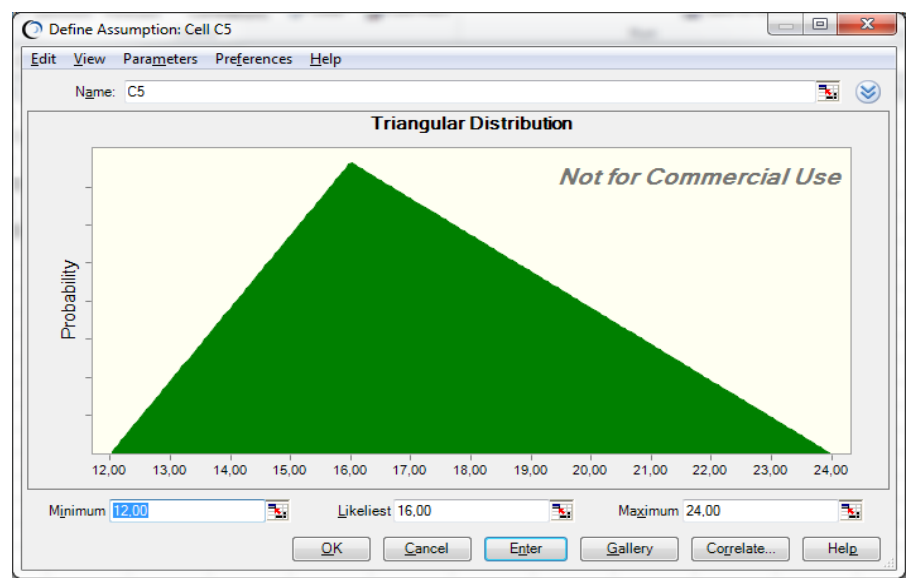

Fig. 2. Triangular distribution for the initial duration 16 


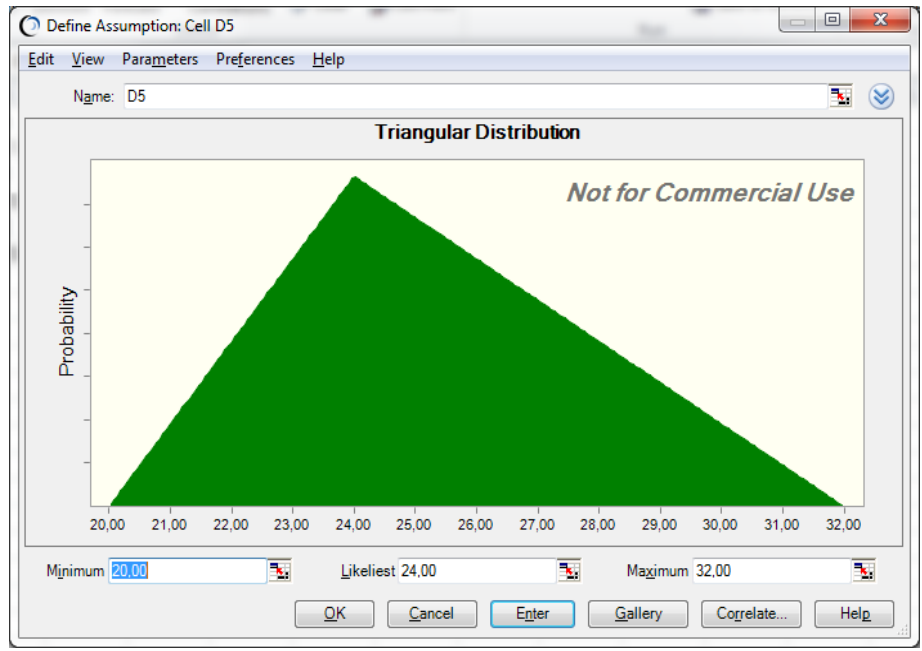

Fig. 3. Triangular distribution for the initial duration 24

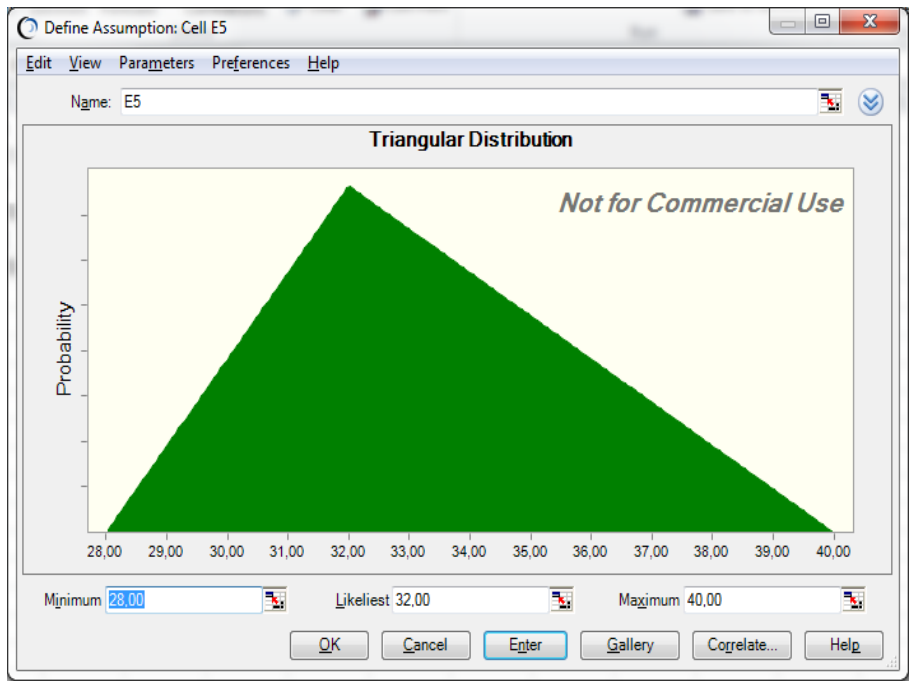

Fig. 4. Triangular distribution for the initial duration 32

On the presented data there was carried out Monte Carlo simulation in Crystal Ball application, a plugin for Excel worksheet. Results of the carried out simulation are shown in the following figure 5 . 


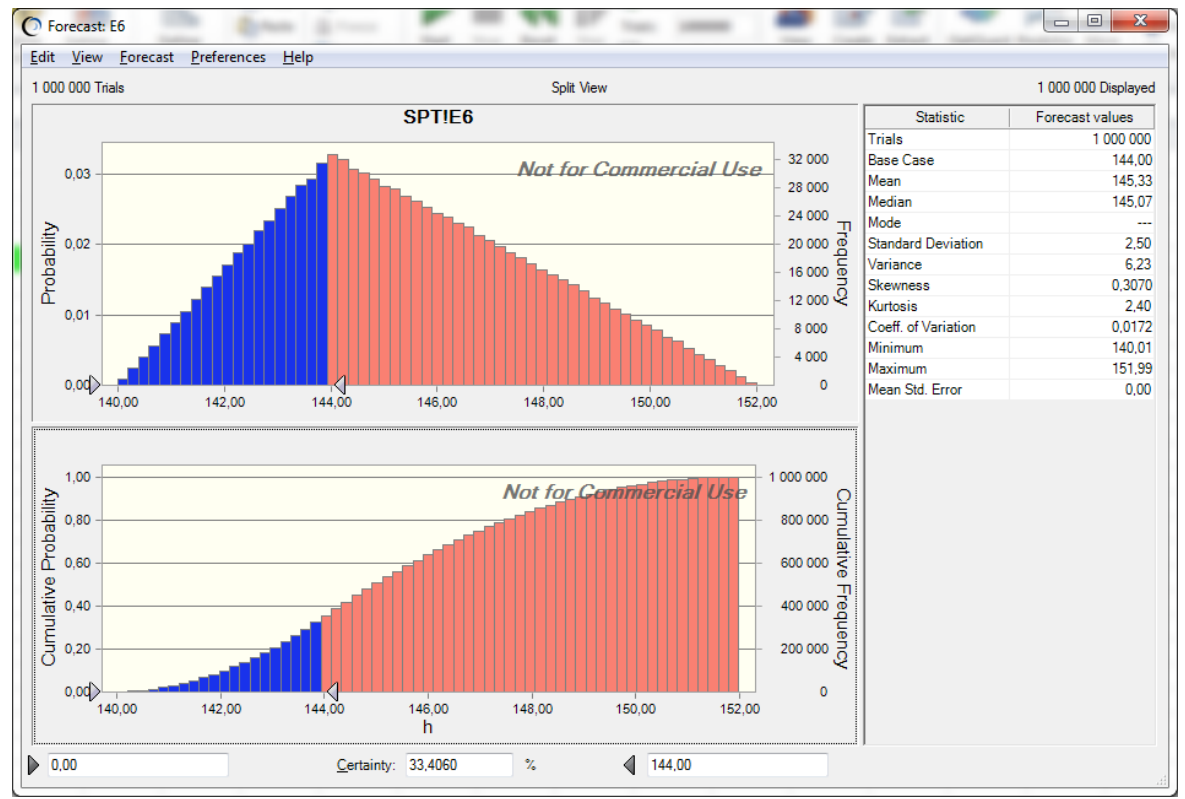

Fig. 5. Results of the simulation performed on a schedule obtained from the application of SPT method

It was read that the minimum time obtained in simulation was 140 , the maximum time was 152 . Probability of holding the directive deadline amounted to $33 \%$.

Another element of the work was scheduling workspaces using LPT rule. The result of the ranking is shown in the following table 3.

Table 3. The results of the scheduling with LPT method

\begin{tabular}{|l|c|c|c|c|}
\hline & Workspace 4 & Workspace 3 & Workspace 2 & Workspace 1 \\
\hline EFT A & 32 & 56 & 72 & 80 \\
\hline EFT B & 64 & 88 & 104 & 112 \\
\hline EFT C & 96 & 120 & 136 & 144 \\
\hline
\end{tabular}

Also in this case shown are calculated completion times of each activity. Probability distributions were also assigned to durations of activities executed by a machine C. Assigned were the same distributions as in the case of SPT method stability evaluation. The following figure 6 shows the results of the carried out simulation experiments. 


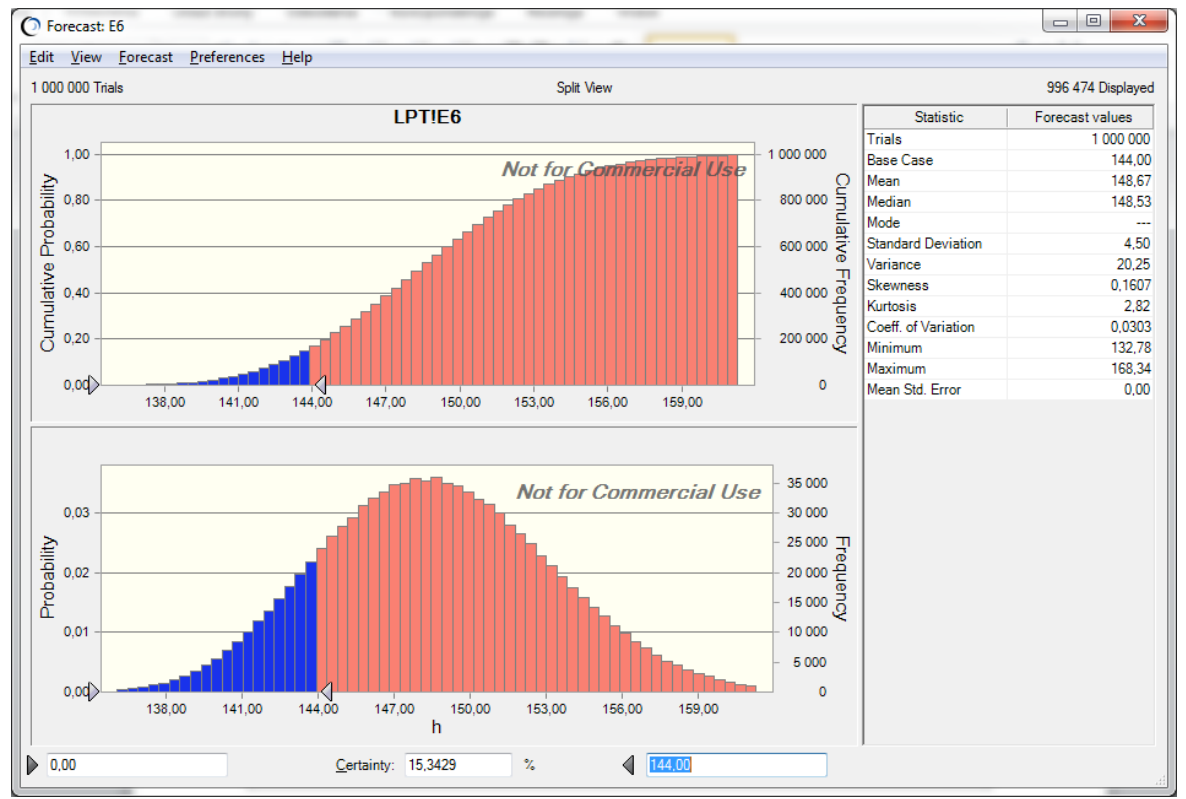

Fig. 6. Results of the simulation performed on a schedule obtained from the application of LPT method

It was read that the minimum time obtained in the simulation was 132 , the maximum time was 168 . Probability of holding the directive deadline was $15 \%$.

Obtained simulation results assessing the stability of schedules are summarized in the table 4 below.

Table 4. Summary of the results of simulations

\begin{tabular}{|c|c|c|c|}
\hline The rule used & Minimum duration & Maximum duration & $\begin{array}{c}\text { Probability of } \\
\text { holding directive } \\
\text { deadline }\end{array}$ \\
\hline SPT & 140 & 152 & 33 \\
\hline LPT & 132 & 168 & 15 \\
\hline
\end{tabular}

It should be noted that using the SPT method in the work of the brigade C popped up most of the total slack time. Thanks to this slack the probability of holding directive deadline has increased twice compared to a schedule from LPT method. In contrast, it was possible to LPT method unnamed getting results for a fraction of the total execution time, it was also possible to obtain the results of the time long. In the SPT method the maximum duration was 152. In the LPT method in 23 percent of all cases this time was longer than the 152. This value is read on the basis of figure 7 located below. 


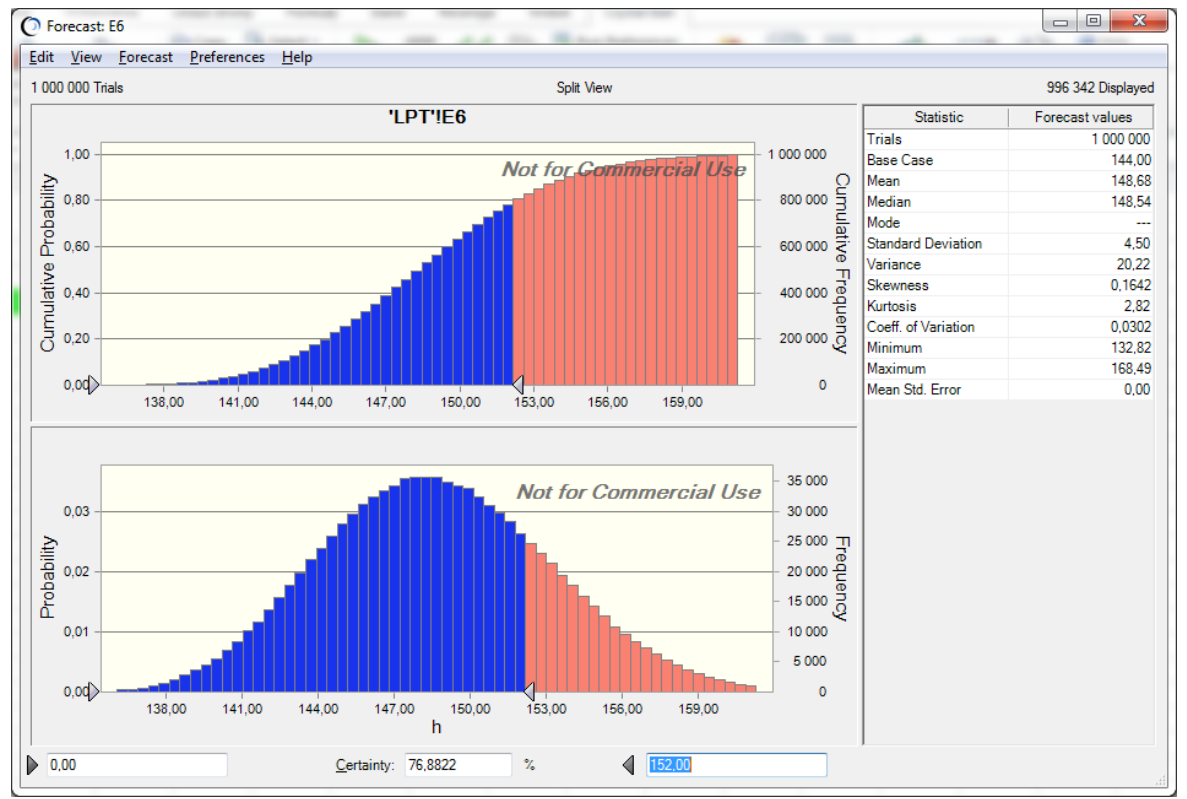

Fig. 7. Results of the simulation performer on a schedule obtained from LPT method, the threshold of 152 time units was marked

\section{STABILITY OF THE RESULTING SCHEDULES FOR CONSTRUCTION NON-HOMOGENEOUS PROCESS WITH USE KASS SOFTWARE}

In the previous chapter the evaluation of the schedules for homogeneous processes was shown - this chapter focuses on the non-homogeneous processes, that is, such that there is no relationship between the size of the plot and the size of the expenditure to be incurred in the execution of all work. Table 5 below shows the worktimes of the 4 working brigades on 7 workspaces.

Table 5. Example data

\begin{tabular}{|c|c|c|c|c|c|c|c|}
\hline & \multicolumn{7}{|c|}{ Time } \\
\cline { 2 - 8 } & Workspace 1 & Workspace 2 & Workspace 3 & Workspace 4 & Workspace 5 & Workspace 6 & Workspace 7 \\
\hline Brigade 1 & 2 & 3 & 7 & 3 & 5 & 2 & 4 \\
\hline Brigade 2 & 4 & 5 & 5 & 4 & 3 & 1 & 2 \\
\hline Brigade 3 & 5 & 4 & 5 & 4 & 3 & 3 & 3 \\
\hline Brigade 4 & 2 & 3 & 6 & 6 & 6 & 3 & 5 \\
\hline
\end{tabular}


Schedule optimization was performed using KASS (www.ipb.edu.pl), using two criteria for a minimum of time and minimum downtime in the brigades' work. [5] The results of the optimization are presented in the following table 6. Shown therein are first five optimal line-ups, total time and total free time of in the work brigades. The program exports the results to the Excel spreadsheet, wherein first 50 best results are saved.

Table 6. KASS schedules

\begin{tabular}{|c|c|c|c|c|c|c|c|c|c|}
\hline Schedule & \multicolumn{7}{|c|}{ KASS order } & \multirow{2}{*}{$\begin{array}{c}\begin{array}{c}\text { Total } \\
\text { time }\end{array} \\
42\end{array}$} & \multirow{2}{*}{$\begin{array}{c}\begin{array}{c}\text { Total } \\
\text { slacktime }\end{array} \\
6\end{array}$} \\
\hline 1 & W4 & W1 & W5 & W2 & W6 & W7 & W3 & & \\
\hline 2 & W4 & W1 & W5 & W2 & W7 & W6 & W3 & 42 & 6 \\
\hline 3 & W4 & W1 & W5 & W6 & W2 & W7 & W3 & 42 & 6 \\
\hline 4 & W4 & W1 & W5 & W6 & W7 & W2 & W3 & 42 & 6 \\
\hline 5 & W4 & W1 & W5 & W6 & W7 & W2 & W3 & 42 & 9 \\
\hline
\end{tabular}

The KASS program runs optimization on the basis of a complete review of all possible solutions. [6] It is only natural that in such an input data layout, there may be much more solutions, however the program doesn't save more than 50 results. It is associated with a large number of carried out calculations [7]. The results obtained show the 5 line-ups of the shortest time and smallest downtime possible. As in the previous case, the worktimes of working brigades had possible timetables probabilities assigned.

It was assumed that the fluctuations may be in work durations of working brigades 2 and 3 . The following table 7 shows durations with their assigned triangular distributions.

Table 7. Durations probability distributions for the brigade 2 and 3

\begin{tabular}{|c|c|c|c|c|c|c|c|c|c|}
\hline \multirow{6}{*}{ 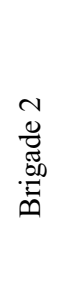 } & $\mathrm{T}$ & Min & Likeliest & Max & \multirow{6}{*}{ 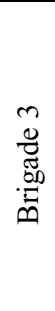 } & $\mathrm{T}$ & Min & Likeliest & Max \\
\hline & 1 & 0,9 & 1 & 1,1 & & 3 & 2,4 & 3 & 3,6 \\
\hline & 2 & 1,8 & 2 & 2,2 & & 5 & 4,0 & 5 & 6,0 \\
\hline & 3 & 2,7 & 3 & 3,3 & & 6 & 4,8 & 6 & 7,2 \\
\hline & 4 & 3,6 & 4 & 4,4 & & & & & \\
\hline & 5 & 4,5 & 5 & 5,5 & & & & & \\
\hline
\end{tabular}

For so modelled schedules a number of simulation in CrystalBall were made. The results are shown in the following table 8 . 
Table 8. Summary of the results of simulations

\begin{tabular}{|c|c|c|c|}
\hline Schedule No & Minimum duration & Maximum duration & $\begin{array}{c}\text { Probability of } \\
\text { holding directive } \\
\text { deadline }\end{array}$ \\
\hline 1 & 41 & 43 & 33 \\
\hline 2 & 41 & 43 & 21 \\
\hline 3 & 41 & 44 & 13 \\
\hline 4 & 41 & 44 & 13 \\
\hline 5 & 41 & 44 & 13 \\
\hline
\end{tabular}

Analyzing the results obtained through the use of simulation techniques, you can easily determine the optimal solution which is line-up number 1 . The deadline was 42 , the probability of holding to it 33 percent. The second solution was a solution no. 2 for which the probability of meeting the directive deadline is 21 percent. You may also notice that in the case of the other three looked-at schedules, the risk of extending time up to 44 occurred, with the likelihood of meeting the directive deadline of 13 percent in all three cases.

\section{SUMMARY}

The aim of this study was to find a solution to the problem, which is scheduling processes that arises from the application of the pipe production method. This occurs quite often where a sizeable building is divided into workspaces in which analogous construction processes will be done. Vary rarely processes are homogenous, we are typically more likely to meet with heterogeneous processes.

The article presents the results of research carried out for the development of a methodology for the selection of a schedule that includes not only the minimum execution time but also as great stability of obtained line-up as possible. All tests were performed on Excel spreadsheet with CrystalBall addin that allows for simulation calculations. Also used was KASS scheduling software, which uses a complete review method.

The article presents two cases. The first is for homogeneous processes. Used here were two scheduling rules of SPT and LPT. The results showed that, in the case of the SPT rules application where there is more downtime results obtained were twice more likely to meet the directive deadline. In the latter case, the focus was on heterogeneous processes. The underlying list is obtained using specialized KASS software. In the case of this type of processes it is possible to obtain a very large number of results that meet established optimization criteria. Selected were the first five, all with the same deadline. After analyses were carried out, an optimal solution has been chosen, whose likelihood of meeting the directive deadline was much better than that of other solutions. 
In summary, it should be noted that in some cases the proposed methodology gives good results and others seem to be debatable. By far the solutions that will have a larger time stocks will be better solutions. It should be clearly noted that in schedules obtained by repetitive processes scheduling it is not possible to determine the time slack. Further work in this direction is currently planned.

\section{REFERENCES}

1. R. Butterworth, "Scheduling theory, Department of Combinatorics and Optimization", University of Waterloo 1979.

2. N. Ibadov, J. Rosłon, "Technology selection for construction project, with the use of fuzzy preference relation", Archives of Civil Engineering, vol. LXI, is. 3, pp. 105-118, 2015.

3. P. Jaśkowski, S. Biruk, „Ocena porównawcza mierników odporności harmonogramów budowlanych" Budownictwo i Inżynieria Środowiska, Vol. 2, no. 4, s. 501—505, 2011.

4. P. Jaśkowski, S. Biruk, , The method for improving stability of construction project schedules through buffer allocation" Technological and Economic Development of Economy, Volume 17(3), pp.429-444, 2011

5. M. Krzemiński, P. Nowak, "Propozycja modyfikacji kosztowej algorytmu Johnsona do szeregowania zadań budowlanych", Wydawnictwo Politechniki Białostockiej "Budownictwo i Inżynieria Środowiska", vol. 2, no. 3, pp. 323-327, 2011.

6. M. Krzemiński, "Use of the KASS program in scheduling", Technical Transaction, ISSUE 2-B(6), pp.217 - 224, 2014.

7. M. Książek, P. Nowak, S. Kivrak, J. Rosłon, L. Ustinovichius, "Computer-aided decision-making in construction project development”, Journal of Civil Engineering and Management, vol. 21, is. 2, pp. 248-259, 2015 .

8. R. Marcinkowski, M. Pokora, „Koncepcja szeregowania zadań dla brygad specjalistycznych w modelach przedsięwzięć typu "kompleks operacji"”, Prace Naukowe Instytutu Budownictwa Politechniki Wrocławskiej. Studia i Materiały, Vol.91, nr 20, pp. 259-268, 2008.

9. M. L. Pinedo, "Scheduling: Theory, Algorithms, and Systems", Springer, 2012.

10. M. L. Pinedo, "Planning and Scheduling in Manufacturing and Services", Springer, 2009.

11. E. Radziszewska-Zielina, B. Szewczyk, "Controlling partnering relations in construction operations using fuzzy reasoning”, Archives of Civil Engineering, vol. LXI, is. 3, pp. 89-104, 2015.

12. E. Radziszewska-Zielina, "Fuzzy control of the partnering relations of a construction enterprise", Journal of Civil Engineering and Management, Vol. 17, No. 1, pp. 5-15, 2011.

13. E. Radziszewska-Zielina, "Analysis of the partnering relations of Polish, Slovak and Ukrainian construction enterprises”, Technological and Economic Development of Economy, Vol. 16, No. 3, 2010, pp. 432-454 


\section{LIST OF FIGURES AND TABLES:}

Fig. 1. Triangular distribution for the initial duration 8

Rys. 1. Rozkład trójkątny dla wyjściowego czasu trwania 8

Fig. 2. Triangular distribution for the initial duration 16

Rys. 2. Rozkład trójkątny dla wyjściowego czasu trwania 16

Fig. 3. Triangular distribution for the initial duration 24

Rys. 3. Rozkład trójkątny dla wyjściowego czasu trwania 24

Fig. 4. Triangular distribution for the initial duration 32

Rys. 4. Rozkład trójkątny dla wyjściowego czasu trwania 32

Fig. 5. Results of the simulation performed on a schedule obtained from the application of SPT method Rys. 5. Wyniki symulacji wykonanej na harmonogramie pozyskanym z zastosowania metody SPT

Fig. 6. Results of the simulation performed on a schedule obtained from the application of LPT method Rys. 6. Wyniki symulacji wykonanej na harmonogramie pozyskanym z zastosowania metody LPT

Fig. 7. Results of the simulation performer on a schedule obtained from LPT method, the threshold of 152 time units was marked

Rys. 7. Wyniki symulacji wykonanej na harmonogramie pozyskanym z zastosowania metody LPT, zaznaczono próg 152 jednostek czasowych.

Tab. 1. Input data

Tab. 1. Dane wejściowe

Tab. 2. The results of the scheduling with SPT method

Tab. 2 Wynik uszeregowania metodą SPT

Tab. 3. The results of the scheduling with LPT method

Tab. 3. Wynik uszeregowania metodą LPT

Tab. 4. Summary of the results of simulations

Tab. 4. Zestawienie wyników symulacji

Tab. 5. Example data

Tab. 5. Dane do przykładu

Tab. 6. KASS schedules

Tab. 6. Harmonogramy z programu KASS

Tab. 7. Durations probability distributions for the brigade 2 and 3

Tab. 7. Rozkłady prawdopodobieństw czasów pracy brygad 2 i 3

Tab. 8. Summary of the results of simulations

Tab. 8. Zestawienie wyników symulacji 


\section{HARMONOGRAMOWANIE BUDOWLANE WRAZ Z OCENA STABILNOŚCI OTRZYMANYCH USZEREGOWAŃ}

Keywords: harmonogramy budowlane, stabilność harmonogramów, metoda potokowa, KASS

\section{STRESZCZENIE:}

W artykule zaprezentowana została koncepcja oceny stabilności harmonogramów budowlanych. Harmonogramy są jednym $\mathrm{z}$ podstawowych narzędziem wykorzystywanym w zarządzaniu projektami budowlanymi. W przypadku projektów, które dotyczą harmonogramowania procesów jednego typu, jednorodnych lub niejednorodnych, istnieje wiele reguł, takich jak MS, FCFS, LPT, SPT, itp., które mogą być stosowane. Można również zastosować różnego rodzaju heurystyki, takie jak modele wąskich gardeł lub lokalnego przeszukiwania oraz wiele innych. Heurystyki te są tworzone każdego dnia. Procesy budowlane są szczególnie podatne na zagrożenia. Niepewność stała się jednym z głównych czynników wpływających na wykonanie projektu i na ostateczny sukces. Ryzyko w działalności budowlanej jest bardzo wysokie. To bardzo ważne, aby pracować z ryzykiem, jednym ze sposobów jest, wybór najbardziej stabilnego harmonogramu. Projekt budowlane charakteryzują się dużą liczbą uczestników. Planowanie projektu w niepewności i ryzyku jest przedmiotem licznych prac badawczych od czasu wprowadzenia modelu PERT. Istniejące metody, które wyrażają czasy trwania jako zmienne losowe, koncentrują się głównie na szacowaniu prawdopodobieństwa dotrzymania terminu dyrektywnego lub czasu trwania projektu na predefiniowanym poziomie ufności wyniku. W artykule zaprezentowane zostały metody oceny stabilności harmonogramów wykonanych z zastosowanie potokowych metod produkcji. Pierwszym rozpatrywanym zagadnieniem była ocena stabilności dwóch harmonogramów uszeregowaniem z zastosowaniem reguł SPT i LPT opracowanych dla procesów jednorodnych.

Należy zauważyć że przy zastosowaniu metody SPT w pracach ostatniej brygady pojawiło się najwięcej całkowitych zapasów czasu. Dzięki tym zapasom dwukrotnie wzrosło prawdopodobieństwo dotrzymania terminu dyrektywnego w porównaniu do uszeregowania metodą LPT. W uszeregowaniu metodą LPT możliwe było natomiast uzyskiwanie wyników o krótszym łącznym czasie wykonania, było także możliwe uzyskiwanie wyników o czasie dłuższym. Drugim zagadnieniem jakie zostało przebadane była ocena harmonogramów wykonanych dla procesów niejednorodnych. Naturalnie i w tym przypadku można by się posłużyć regułami szeregowania zadań. Autor jednak stwierdził że dla uzyskania lepszych wyników zastosowany zostanie program KASS który działając na zasadzie przeglądu zupełnego gwarantuje otrzymanie wyniku najlepszego lub grupy wyników najlepszych. Właśnie z tej grupy należy wybrać harmonogram odporny na zakłócenia. Proponowana metoda oceny stabilności harmonogramów należy do metod symulacyjnych. Autor założył że po otrzymaniu grupy harmonogramów wybranym czynnościom zostaną przypisane rozkłady prawdopodobieństw. Następnie zostanie przeprowadzona symulacja, dzięki której otrzymane zostaną rozkład prawdopodobieństwa i dystrybuanta dla badanego w tym przypadku terminu dyrektywnego. Czym większy poziom ufności tym rozwiązanie można uznać za lepsze, pewniejsze. Wszystkie symulacje zostały przeprowadzone w programie CrystallBall. Podsumowując należy stwierdzić że w niektórych przypadkach proponowana metodyka daje dobre wyniki a w innych takie które wydają się być dyskusyjne. Zdecydowanie rozwiązania które będą posiadały większe zapasy czasu będą rozwiązaniami lepszymi w rozumieniu bardziej odpornymi na zakłócenia. Przewiduje się dalsze prace w tym kierunku. 